Article

\title{
Catalytic epoxidation of olefin over supramolecular compounds of molybdenum oxide clusters and a copper complex
}

\author{
Hongcheng Gao a, Yan Yan ${ }^{b}$, Xiaohong Xu c, Jiehui Yu ${ }^{b}$, Huiling Niu ${ }^{\text {b }}$, Wenxiu Gao ${ }^{\text {b }}$, \\ Wenxiang Zhang ${ }^{b}$, Mingjun Jia ${ }^{b, *}$ \\ a Department of Chemical Engineering, Chengde Petroleum College, Chengde 067000, Hebei, China \\ b College of Chemistry, Jilin University, Changchun 130021, Jilin, China \\ c Pharmacy Department, Daqing Oilfield General Hospital, Daqing 163001, Heilongjiang, China
}

\section{A R T I C L E I N F O}

Article history:

Received 1 May 2015

Accepted 29 May 2015

Published 20 November 2015

\section{Keywords:}

Supramolecular compound

Molybdenum oxide cluster

Copper complex

Olefin

Epoxidation

\begin{abstract}
A B S T R A C T
The catalytic epoxidation of olefin was investigated on two copper complex-modified molybdenum oxides with a 3D supramolecular structure, $[\mathrm{Cu}(\text { bipy })]_{4}\left[\mathrm{Mo}_{15} \mathrm{O}_{47}\right] \cdot 2 \mathrm{H}_{2} \mathrm{O}(\mathbf{1})$ and $\left[\mathrm{Cu}^{\mathrm{l}}(\mathrm{bix})\right]\left[\left(\mathrm{Cu}{ }^{\prime} \mathrm{bix}\right)\right.$ $\left.\left(\delta \text { - } \mathrm{Mo}^{\mathrm{VI}_{8} \mathrm{O}_{26}}\right)_{0.5}\right]$ (2) (bipy = 4,4'-bipyridine, bix = 1,4-bis(imidazole-1-ylmethyl)benzene). Both compounds were catalytically active and stable for the epoxidation of cyclooctene, 1-octene, and styrene with tert-butyl hydroperoxide $(t-\mathrm{BuOOH})$ as oxidant. The excellent catalytic performance was attributed to the presence of stable coordination bonds between the molybdenum oxide and copper complex, which resulted in the formation of easily accessible Mo species with high electropositivity. In addition, the copper complex also acted as an active site for the activation of $t-\mathrm{BuOOH}$, thus improving these copper complex-modified polyoxometalates.
\end{abstract}

(C) 2015, Dalian Institute of Chemical Physics, Chinese Academy of Sciences. Published by Elsevier B.V. All rights reserved.

\section{Introduction}

The design and synthesis of inorganic-organic hybrid materials based on polyoxometalates (POMs) have become a significant research area due to their interesting structures and numerous potential applications in material science, medicine, magnetism, electrochemistry, and catalysis [1-6]. Recently, a new class of supramolecular compound composed of a transition metal (e.g., $\mathrm{Cu}, \mathrm{Ni}$, and $\mathrm{Ag}$ ) complex (TMC) and POM units have drawn considerable attention because the combination of a transition metal complex with POMs can help construct versatile intriguing supramolecular structures, and have novel physicochemical properties for various applications [7-14].

In the catalytic application of POM-based compounds, more recent studies have focused on developing highly active and stable heterogeneous POM-based catalysts for the epoxidation of olefins, which are important processes for the production of fine chemicals [15]. Recently, Ali's group [16] synthesized two novel copper complex-modified Anderson type POMs, $\left[\left(\mathrm{Na}_{4}\left(\mathrm{H}_{2} \mathrm{O}\right)_{14}\right)(\mathrm{Cu}(\text { gly }))_{2}\right]\left[\mathrm{TeMo}_{6} \mathrm{O}_{24}\right]$ (gly = glycine) and $\left[\left(\mathrm{Cu}(\mathrm{en})_{2}\right)_{3}\left(\mathrm{TeW}_{6} \mathrm{O}_{24}\right)\right] \cdot 6 \mathrm{H}_{2} \mathrm{O}$ (en = ethylene-diamine), and found that these compounds showed moderate catalytic activity for the epoxidation of styrene and cyclohexene with tertbutylhydroperoxide $(t-\mathrm{BuOOH})$. In a work reported by Cui and co-authors [17], it was found that a few hybrid compounds composed of POMs, transition metal ions $\left(\mathrm{Ni}^{2+}, \mathrm{Cu}^{2+}\right.$, and $\left.\mathrm{Cd}^{2+}\right)$, and a 4,4'-bipyridine organic ligand were active for the epoxidation of styrene. Currently, it is still a very attractive subject to develop more efficient and stable TMC-modified POMs as catalysts for olefin epoxidation.

* Corresponding author. Tel: +86-431-85155390; Fax: +86-431-85168420; E-mail: jiamj@jlu.edu.cn 
Previously, we reported that some $N$-heterocyclic ligandsmodified octamolybdate-based supramolecular compounds were active heterogeneous catalyst for the epoxidation of cyclooctene and 1-octene with $t$ - $\mathrm{BuOOH}$. The formation of a multidimensional supramolecular structure using multiple weak interactions, such as hydrogen bonds and $\pi-\pi$ interactions, plays a key role in fabricating active and stable POM-based catalysts. The catalytic properties varied considerably with the organic ligand and the multidimensional supramolecular structure [18]. As a continuation of the work, we investigated the catalytic epoxidation properties of two copper complexes used to modify molybdenum oxides, [Cu(bipy) $]_{4}\left[\mathrm{Mo}_{15} \mathrm{O}_{47}\right]$. $2 \mathrm{H}_{2} \mathrm{O}$ (1) (bipy $=4,4^{\prime}$-bipyridine) and $\left[\mathrm{Cu}^{\mathrm{I}}(\right.$ bix $\left.)\right]\left[\left(\mathrm{Cu}^{\mathrm{l} b i x}\right)(\delta\right.$ $\left.\mathrm{MoVI}_{8} \mathrm{O}_{26}\right)_{0.5}$ ] (2) (bix = 1,4-bis(imidazole-1-ylmethyl)benzene). The structures and electrochemical properties of these two compounds have recently been studied by two research groups $[13,14]$. In the present work, it was found that both compounds $\mathbf{1}$ and $\mathbf{2}$ exhibited excellent catalytic activity and stability for the epoxidation of olefins. The role of the copper complexes was discussed on the basis of the structural characteristics and catalytic properties of these transition metal complex-modified POMs catalysts.

\section{Experimental}

\subsection{Synthesis of the catalysts}

\subsection{1. $[\mathrm{Cu}(\text { bipy })]_{4}\left[\mathrm{Mo}_{15} \mathrm{O}_{47}\right] \cdot 2 \mathrm{H}_{2} \mathrm{O}$ (1)}

Bipy (0.5 mmol, $0.0961 \mathrm{~g}), \mathrm{Cu}(\mathrm{OAc})_{2} \cdot \mathrm{H}_{2} \mathrm{O}(0.5 \mathrm{mmol}, 0.099$ g), $\left(\mathrm{NH}_{4}\right)_{6} \mathrm{Mo}_{7} \mathrm{O}_{24} \cdot 4 \mathrm{H}_{2} \mathrm{O}(0.2 \mathrm{mmol}, 0.248 \mathrm{~g})$, and triethylamine (0.02 $\mathrm{mL}$ ) were added into $15 \mathrm{~mL}$ of distilled water at room temperature. The $\mathrm{pH}$ of the mixture was adjusted to 3.0 with $\mathrm{HCl}$ solution (1 mol/L). After stirring for $1 \mathrm{~h}$ at room temperature, the mixture was transferred to a sealed Teflon-lined autoclave $(25 \mathrm{~mL})$ and heated at $170{ }^{\circ} \mathrm{C}$ for $5 \mathrm{~d}$. When the mixture was slowly cooled $\left(10^{\circ} \mathrm{C} / \mathrm{h}\right)$ to room temperature, brown block crystals of 1 were obtained after washing with distilled water. The crystals were dried at room temperature and gave a yield of $40 \%$ based on Mo.

\subsection{2. $\quad\left[\mathrm{Cu}^{\mathrm{I}}(\mathrm{bix})\right]\left[\left(\mathrm{Cu}{ }^{\mathrm{l}} \mathrm{bix}\right)\left(\mathrm{C}-\mathrm{Mo}^{V I_{8} \mathrm{O}_{26}}\right)_{0.5}\right](2)$}

$\mathrm{CuCl}_{2} \cdot 2 \mathrm{H}_{2} \mathrm{O}$ (0.5 mmol, $0.085 \mathrm{~g}$ ), bix (0.5 mmol, $0.119 \mathrm{~g}$ ), $\left(\mathrm{NH}_{4}\right)_{6} \mathrm{Mo}_{7} \mathrm{O}_{24} \cdot 4 \mathrm{H}_{2} \mathrm{O}(0.1 \mathrm{mmol}, 0.124 \mathrm{~g})$, and triethylamine $(0.02 \mathrm{~mL})$ were added into $15 \mathrm{~mL}$ of distilled water. The $\mathrm{pH}$ of the mixture was adjusted to 5.0 with $\mathrm{HCl}$ or $\mathrm{NaOH}$ solution (1 mol/L). After stirring for $1 \mathrm{~h}$ at room temperature, the mixture was transferred into a sealed Teflon-lined autoclave $(25 \mathrm{~mL})$ and heated at $170{ }^{\circ} \mathrm{C}$ for $5 \mathrm{~d}$. Red block crystals of 2 were collected after the mixture was slowly cooled $\left(10{ }^{\circ} \mathrm{C} / \mathrm{h}\right)$ to room temperature. The crystals were washed with distilled water and dried at room temperature to give a yield of $45 \%$ based on Mo.

\subsubsection{Reference sample $\left(\mathrm{H}_{2}\right.$ bix $)\left[(\mathrm{Hbix})_{2}\left(\gamma-\mathrm{Mo}_{8} \mathrm{O}_{26}\right)\right] 2 \cdot \mathrm{H}_{2} \mathrm{O}$ (3)}

The synthesis of $\mathbf{3}$ was similar to that of $\mathbf{2}$, but without the addition of triethylamine and $\mathrm{CuCl}_{2} \cdot 2 \mathrm{H}_{2} \mathrm{O}$. The crystals of 3 were collected with a yield of $49 \%$ based on Mo.

\subsection{Characterization of the catalysts}

Crystallographic data for all compounds were collected at $120^{\circ} \mathrm{C}$ on a Siemens SMART CCD using graphite-monochromatized Mo $K_{\alpha}$ radiation $(\lambda=0.071073 \mathrm{~nm})$. Absorption corrections were carried out with the SADABS program. The structure was solved by direct methods and refined on $\mathrm{F}_{2}$ by the full matrix least squares technique with the SHELXL-97 program software [19]. Geometric calculations were used to locate the positions of the hydrogen atoms. Fourier transform infrared (FT-IR) spectra (KBr pellets) were recorded with a Nicolet Impact 410 spectrometer. Powder X-ray diffraction (XRD) patterns were obtained on a Shimadzu XRD-6000 diffractometer with $\mathrm{Cu} K_{\alpha}$ radiation range from $5^{\circ}$ to $70^{\circ}$ at a scan rate of $6 \%$ min. X-ray photoelectron spectroscopy (XPS) analysis was carried out on a Thermo ESCALAB 250 spectrometer with an $\operatorname{Mg} K(1253.6 \mathrm{eV})$ achromatic X-ray source.

\subsection{Catalytic test}

The activity and selectivity of all the catalysts were studied using the epoxidation of various olefins with $t$-BuOOH as oxidant and chloroform or acetonitrile as the solvent. Typically, the epoxidation of olefins was performed in a $10 \mathrm{~mL}$ roundbottomed flask equipped with a reflux condenser at a temperature of 35,45 , or $61^{\circ} \mathrm{C}$. The catalyst $(0.005 \mathrm{mmol})$, substrate (1.0 mmol), $t$-BuOOH (1.0 mmol), and solvent (chloroform or acetonitrile, $2 \mathrm{~mL}$ ) were added into the flask. Samples were withdrawn at regular intervals and filtered before measurement by a gas chromatograph (Shimadzu GC-14C FID). The catalytic performance of catalyst was evaluated by the conversion of olefin and selectivity to its epoxide using toluene as the internal standard.

\section{Results and discussion}

\subsection{Synthesis and structure of the catalysts}

The procedures for the synthesis of compounds $\mathbf{1}$ and $\mathbf{2}$ were similar to those in the literature [13,14]. Minor modification such as using different reagents and synthesis conditions ( $\mathrm{pH}$ values, heating temperatures) were used in order to get crystalline products with high quality and yield. For instance, the reagent $\mathrm{NH}_{4} \mathrm{VO}_{3}$ was used for the synthesis of compound $\mathbf{1}$ in the literature [13], but our present work confirmed that the introduction of this $\mathrm{V}$-containing reagent was not necessary and a relatively high yield of $\mathbf{1}$ can be achieved by the optimized synthesis conditions described in the experimental section.

Single crystal XRD analysis revealed that compound $\mathbf{1}$ has an open multitrack $\mathrm{Cu}-\mathrm{N}$ coordination polymeric chain-modified molybdenum oxide 3D supramolecular structure (Fig. 1(a)), which is consistent with the previously reported structure in the literature [13]. The molecular structure unit of $\mathbf{1}$ consists of one molybdenum oxide chain of $\left[\mathrm{Mo}_{15} \mathrm{O}_{47}\right]^{4-}$, four $[\mathrm{Cu} \text { (bipy) }]^{+}$cations, and two water molecules (Fig. 2). Compound 2 showed a 3D $(4,4)$-connected framework with the 
$\left(6^{4} 8^{2}\right)\left(8^{4} 12^{2}\right)$ topology, which is constructed from $\delta$-octamolybdates $[20,21]$, copper cations, and bix ligands. The structure of 2 has been reported in the literature [14]. The main feature of this compound is that its 3D framework is penetrated by copper-organic polymeric chains to form a 3D polythreaded framework (Fig. 1(b)). The unit cell of 2 shows the presence of a $\left[\delta-\mathrm{Mo}_{8} \mathrm{O}_{26}\right]^{4-}$ anion, two $\mathrm{Cu}^{\mathrm{I}}(\mathrm{Cu} 1$ and $\mathrm{Cu} 2)$ cations and two bix1 (Z-type) and bix2 (U-type) ligands (Fig. 2(c)).

The reference sample of compound $\mathbf{3}$ exhibited a 3D supramolecular framework based on hydrogen bond interactions and $\pi-\pi$ stacking interactions between the bix ligands and $\left[(\mathrm{Hbix})_{2}\left(\gamma-\mathrm{Mo}_{8} \mathrm{O}_{26}\right)\right]^{2-}$ units (Fig. 3). The molecular structure of 3 consists of one $\left[(\mathrm{Hbix} 1)_{2}\left(\gamma-\mathrm{Mos}_{8} \mathrm{O}_{26}\right)\right]^{2-}$ unit, one $\left(\mathrm{H}_{2} \mathrm{bix} 2\right)^{2+}$ cation, and one lattice water.

\subsection{Catalytic properties}

The catalytic properties of catalysts $\mathbf{1}$ and $\mathbf{2}$ and reference sample $\mathbf{3}$ were investigated for the epoxidation of cyclooctene and 1-octene with $t$-BuOOH as the oxidant. As shown in Table 1, all catalysts were active for the epoxidation of olefins with nearly $100 \%$ selectivity to the corresponding epoxides. Among these, catalyst 1 showed the highest activity, and 96\% conver- sion of cyclooctene was reached after $8 \mathrm{~h}$ reaction at the low temperature of $35^{\circ} \mathrm{C}$.

Catalyst 2 was also active, and 92\% conversion of cyclooctene was achieved after $10 \mathrm{~h}$. Both the copper complexmodified POM catalysts exhibited much higher activity than the reference sample $\mathbf{3}$ (39\% conversion of cyclooctene after $10 \mathrm{~h}$ ). In addition, the relatively inert terminal olefin of 1-octene can be also converted rapidly to the corresponding epoxide $(77 \%$ conversion, nearly $100 \%$ epoxide selectivity, reaction time 12 h) when 1 was used as catalyst. It should be mentioned here that some byproducts like 1,2-octanediol and 1-octanal were also detected when the reaction time was further prolonged (data not given).

The epoxidation of styrene was also investigated over the above catalysts (Table 2). When chloroform was chosen as the solvent, the catalytic activity of these three catalysts decreased in the order of $\mathbf{1}>\mathbf{2}>\mathbf{3}$. A significant amount of byproducts like benzaldehyde and penylacetaldehyde were observed over these catalysts, thus considerably decreasing the selectivity to epoxide (particularly seriously on the two copper complexmodified POM catalysts). Changing the solvent from chloroform to acetonitrile did not change the activity order of the catalysts, but the selectivity to epoxide decreased notably with the in-

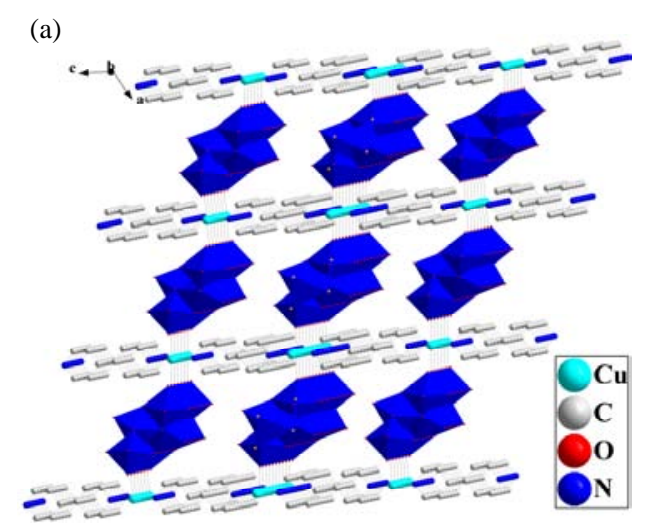

(b)

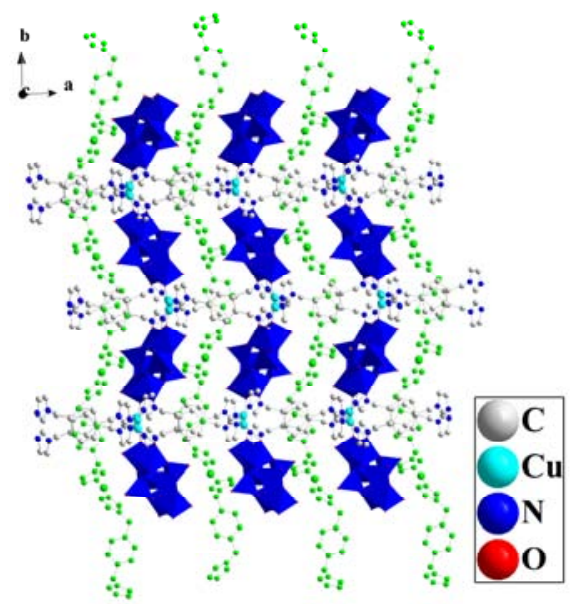

Fig. 1. (a) View of the infinite-track Cu(bipy) chain-modified $\left[\mathrm{Mo}_{15} \mathrm{O}_{47}\right]_{n}{ }^{4 n-}$ in compound 1; (b) The 3D polythreaded supramolecular structure along the given directions in compound $\mathbf{2}$ (green represents penetrated $[\mathrm{Cu} 2 \text { (bix2) }]_{n}{ }^{+}$chains).

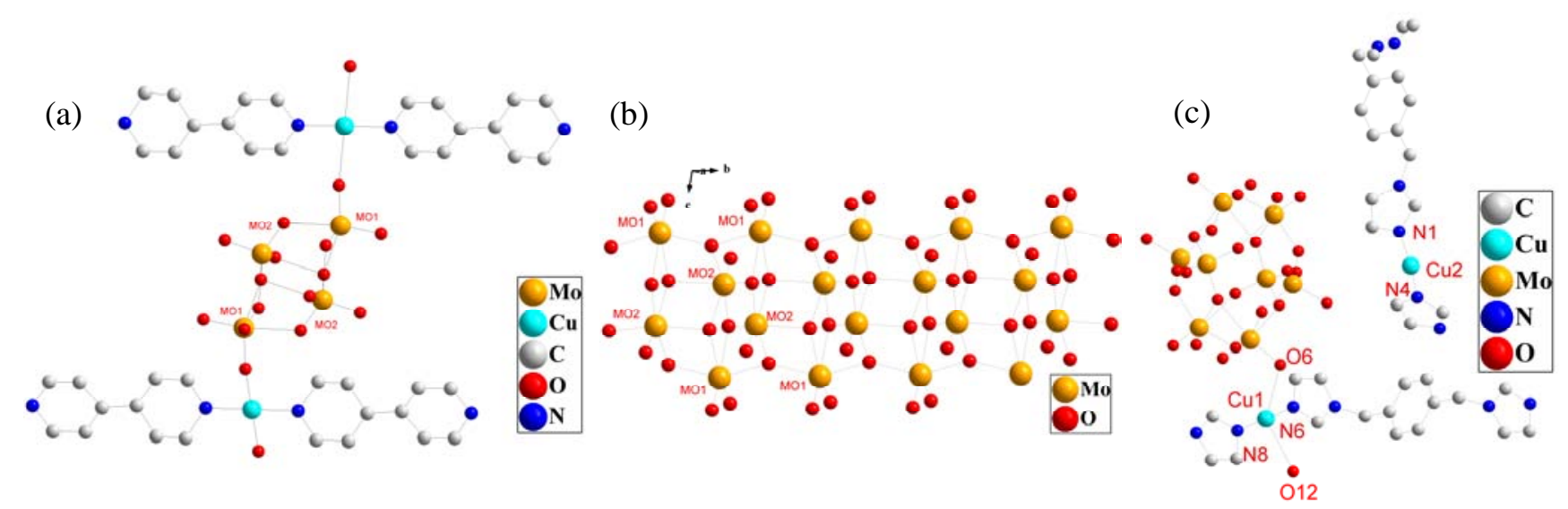

Fig. 2. Ball and stick representation of the molecular unit (a) and $\left.\left[\mathrm{Mo}_{15} \mathrm{O}_{47}\right]\right]_{n^{4 n-}}$ chains (b) of compound $\mathbf{1}$; (c) Ball and stick representation of the molecular unit of compound $\mathbf{2}$ (all hydrogen atoms and lattice water molecules were omitted for clarity). 


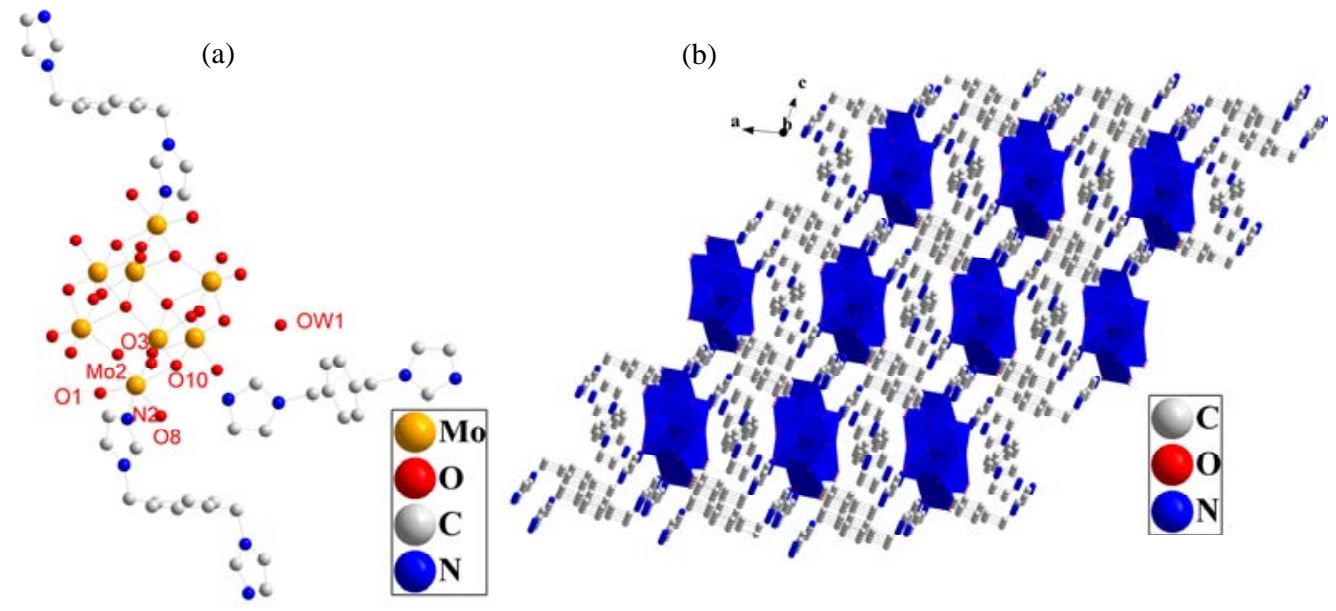

Fig. 3. (a) Ball and stick representation of the molecular unit of compound 3; (b) 3D supramolecular framework in compound 3.

crease of benzaldehyde selectivity. Very high benzaldehybe selectivity (up to 96\%) was found over the copper-free catalyst 3. These results suggest that the catalytic performance of these POM-based catalysts was solvent dependent [22].

To verify the heterogeneity of the catalytic process, a leaching test was performed for the epoxidation of 1-octene over the two copper complex-modified POM catalysts. As shown in Fig. 4 , both catalyst 1 and catalyst $\mathbf{2}$ show very high stability against leaching of the active species. Besides, it was also found that these catalysts are recyclable, and no loss in catalytic activity was detected after five reaction cycles (Fig. 5). These results suggested that the copper complex-modified POM compounds are truly heterogeneous catalysts under the reaction conditions employed.

Table 1

Epoxidation of olefins catalyzed by catalysts 1, 2, and 3 .

\begin{tabular}{|c|c|c|c|c|c|}
\hline Catalyst & Substrate & Product & $\begin{array}{c}t \\
\left({ }^{\circ} \mathrm{C}\right)\end{array}$ & $\begin{array}{c}\text { Time } \\
\text { (h) }\end{array}$ & $\begin{array}{c}\text { Conversion } \\
(\%)\end{array}$ \\
\hline 1 & & & 35 & 8 & 96 \\
\hline 2 & & & 35 & 10 & 92 \\
\hline 3 & & & 35 & 10 & 39 \\
\hline 1 & & & 61 & 12 & 77 \\
\hline 2 & & & 61 & 12 & 44 \\
\hline 3 & & & 61 & 12 & 43 \\
\hline
\end{tabular}

Reaction conditions: substrate $1.0 \mathrm{mmol}$; $t$-BuOOH $1.0 \mathrm{mmol}$; catalyst $0.005 \mathrm{mmol}$; chloroform $2.0 \mathrm{~mL}$. All selectivities for the epoxide were nearly $100 \%$.

Table 2

Epoxidation of styrene over the three catalysts after $12 \mathrm{~h}$ reaction time.

\begin{tabular}{|c|c|c|c|c|c|}
\hline \multirow[b]{2}{*}{ Catalyst } & \multirow[b]{2}{*}{ Solvent } & \multirow[b]{2}{*}{$\begin{array}{c}\text { Conversion } \\
(\%)\end{array}$} & \multicolumn{3}{|c|}{ Selectivity (\%) } \\
\hline & & & & & \\
\hline 1 & chloroform & 98 & 37 & 48 & 15 \\
\hline 2 & & 77 & 40 & 47 & 13 \\
\hline 3 & & 67 & 63 & 10 & 26 \\
\hline 1 & acetonitrile & 91 & 9.0 & 73 & 17 \\
\hline 2 & & 70 & 11 & 77 & 10 \\
\hline 3 & & 21 & 2.5 & 96 & 1.3 \\
\hline
\end{tabular}

Reaction conditions: styrene $1.0 \mathrm{mmol} ; t$-BuOOH $1.0 \mathrm{mmol}$; catalyst $0.005 \mathrm{mmol}$; solvent $2.0 \mathrm{~mL}$; temperature $61^{\circ} \mathrm{C}$.
FT-IR and XRD measurements were carried out to investigate the structural stability of catalyst 1 . The FT-IR spectra showed that there was no obvious difference between the used catalyst (after the 5 th reaction of 1-octene epoxidaiton) and the

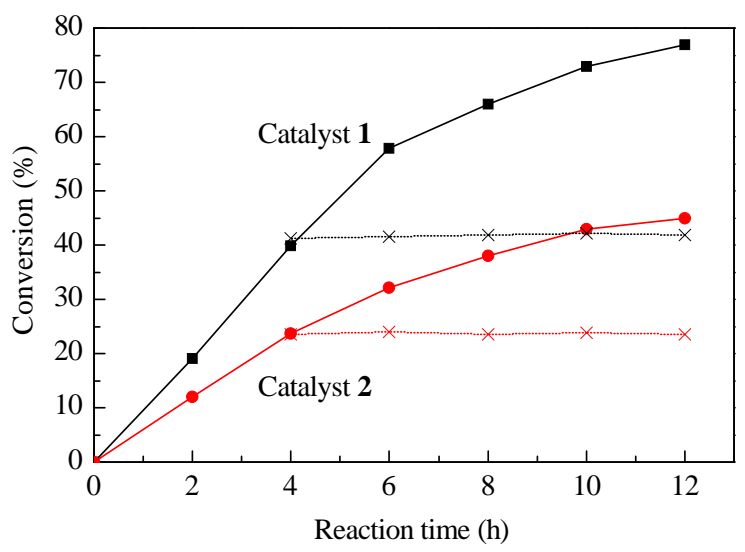

Fig. 4. Kinetic profiles of the epoxidation of 1-octene with $t$-BuOOH over the catalysts. $(\mathbf{x})$ Leaching experiments of the catalysts indicating conversion of 1-octene with the catalysts removed after $4 \mathrm{~h}$ at reaction temperature. Reaction conditions: 1-octene $1.0 \mathrm{mmol}$; $t$-BuOOH 1.0 mmol; catalyst $0.005 \mathrm{mmol}$; chloroform $2.0 \mathrm{~mL}$; temperature $61^{\circ} \mathrm{C}$. All selectivities for the epoxide were nearly $100 \%$.

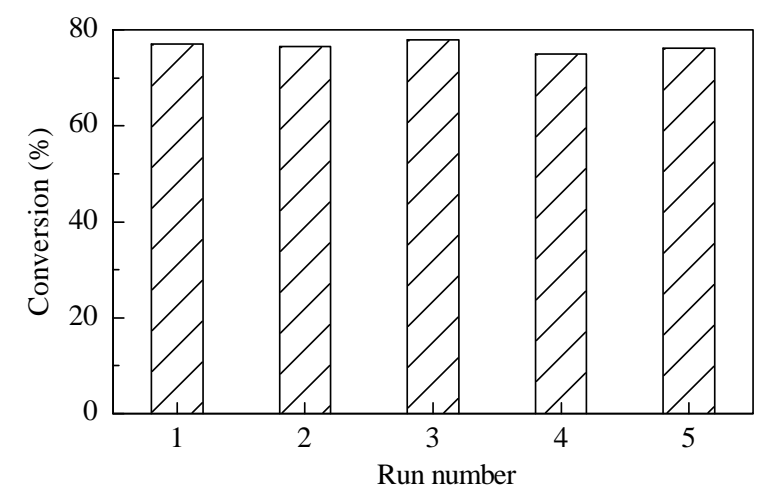

Fig. 5. Recycling experiments of catalyst $\mathbf{1}$ for the conversion of 1-octene after $12 \mathrm{~h}$ reaction. Reaction conditions: 1-octene $1.0 \mathrm{mmol}$; $t$-BuOOH $1.0 \mathrm{mmol}$; catalyst $0.005 \mathrm{mmol}$; chloroform $2.0 \mathrm{~mL}$; temperature $61^{\circ} \mathrm{C}$. All selectivities for the epoxide were nearly $100 \%$. 


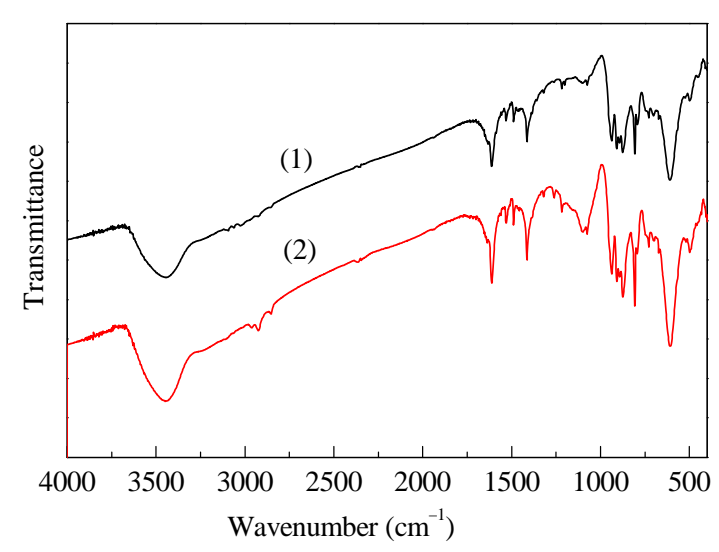

Fig. 6. FT-IR spectra of fresh catalyst 1 (1) and used one after the fifth cycle in 1-octene epoxidation (2).

fresh one (Fig. 6). The XRD patterns indicated that the characteristic diffraction peaks for the used catalyst were consistent with the fresh catalyst 1 (Fig. 7). These results suggested that the molecular structure geometry of catalyst $\mathbf{1}$ was kept during the reaction process. The high catalytic stability of the copper complex modified POM compounds can be attributed to the formation of the stable 3D supramolecular structure. It was discussed above that the copper complex and molybdenum oxide clusters were coordinately connected via the terminal oxygen atoms of the molybdenum oxide cluster (as active coordination sites) and the copper ions.

XPS measurements were also carried out for the two copper complex-modified POM catalysts (Fig. 8). The XPS spectrum of catalyst 1 showed two peaks at 235.9 and $232.6 \mathrm{eV}$, which were assigned to Mo $3 d_{3 / 2}$ and Mo $3 d_{5 / 2}$, respectively. For catalyst 2 , a slightly lower binding energy of the Mo species (235.3 and $232.1 \mathrm{eV}$ ) was detected. The higher electropositivity of Mo species is associated with the higher catalytic activity of molybdenum-containing catalysts [23]. This may be the main reason why catalyst 1 was more active than 2 . The high electropositivity of catalyst 1 originated from the nature of the molybdenum oxide, i.e., $\left[\mathrm{Mo}_{15} \mathrm{O}_{47}\right]^{4-}$.

Furthermore, the introduction of the copper complex into the framework of the POM-based compounds also considerably influenced the electropositivity of the Mo species by a strong

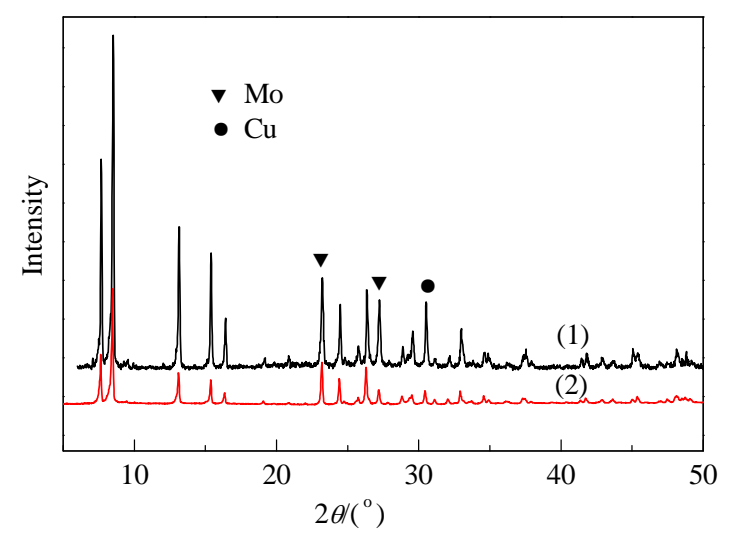

Fig. 7. XRD patterns of fresh catalyst $\mathbf{1}$ (1) and the used one after the fifth cycle in 1-octene epoxidation (2).

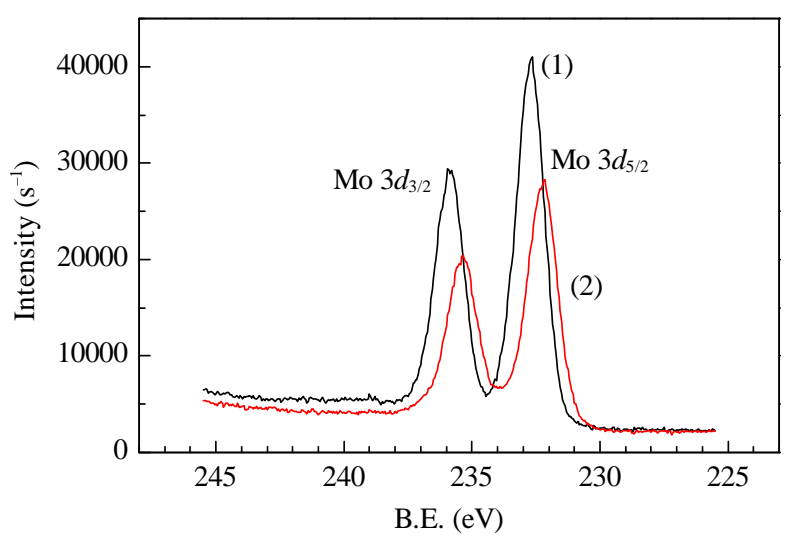

Fig. 8. XPS spectra of catalysts 1 (1) and 2 (2).

interaction (i.e., forming a coordination bond) between the POM units and the copper complex. This interaction can change the nature of the active Mo species, thus resulting in that the copper complex-modified POM catalysts ( $\mathbf{1}$ and 2 ) showed different catalytic activity and selectivity for the epoxidation of olefins compared to the copper-free POM catalyst (3). In addition, the introduced copper complex can also act as a new active site for the activation of $t$-BuOOH to form the active intermediate, like the $\mathrm{Cu}$-hydroperoxo species, which has been proposed in the literature [16,24-27]. This may be another important contribution from the copper complex to the improvement of the catalytic activity of the POM-based catalysts.

Other factors such as the structural characteristics of the POM-based catalysts may also influence its catalytic property. Compared with the polythreaded structure of catalyst 2 , catalyst $\mathbf{1}$ has a more open framework, which is more suitable for the diffusion of the reactants to increase the substrate contact with the catalyst active sites, thus helping to improve the catalytic activity of catalyst $\mathbf{1}$.

\section{Conclusions}

Two supramolecular compounds based on molybdenum oxide clusters and copper complexes showed excellent catalytic activity and selectivity for the epoxidation of olefins. Both catalysts are heterogeneous in nature and can be easily recycled without decrease in activity. The presence of relatively strong coordination bonds between the copper complex and the molybdenum oxide clusters played a critical role in fabricating the stable supramolecular structure and in forming an active and stable heterogeneous catalyst for the epoxidation of olefins.

\section{References}

[1] Müller A, Peters F, Pope M T, Gatteschi D. Chem Rev, 1998, 98: 239

[2] Coronado E, Gómez-García C J. Chem Rev, 1998, 98: 273

[3] Carlucci L, Ciani G, Proserpio D M. Coord Chem Rev, 2003, 246: 247

[4] Rao C N R, Natarajan S, Vaidhyanathan R. Angew Chem Int Ed, 2004, 43: 1466

[5] Xu X, Ju W W, Hou W T, Zhu D R, Xu Y. CrystEngComm, 2014, 16: 82

[6] Wang L M, Wang Y, Fan Y, Xiao L N, Hu Y Y, Gao Z M, Zheng D F, Cui 


\section{Graphical Abstract}

Chin. J. Catal., 2015, 36: 1811-1817 doi: 10.1016/S1872-2067(15)60919-6

\section{Catalytic epoxidation of olefin over supramolecular compounds of molybdenum oxide clusters and a copper complex \\ Hongcheng Gao, Yan Yan, Xiaohong Xu, Jiehui Yu, Huiling Niu, Wenxiu Gao, Wenxiang Zhang, Mingjun Jia* \\ Chengde Petroleum College; Jilin University; Daqing Oilfield General Hospital}

Copper complex-modified polyoxometalates showed high catalytic activity and stability in the catalytic epoxidation of olefin with tert-butyl hydroperoxide $(t-\mathrm{BuOOH})$ as oxidant.

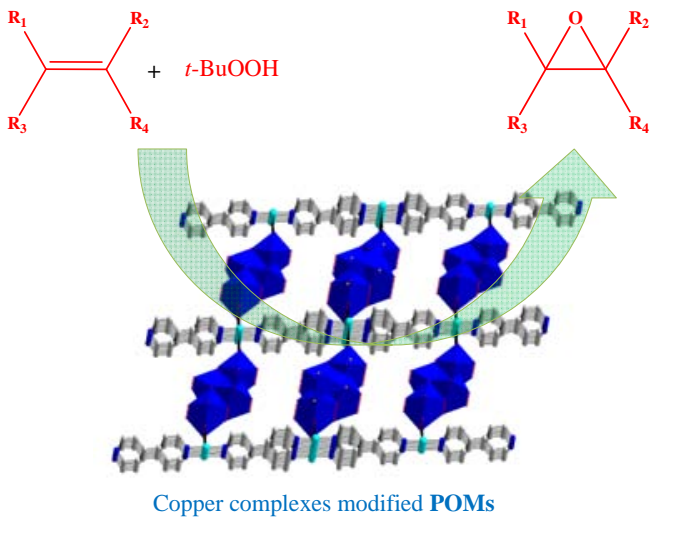

X B, Xu J Q. CrystEngComm, 2014, 16: 430

[7] Wang X L, Li N, Tian A X, Ying J, Liu G C, Lin H Y, Zhang J W, Yang Y. Dalton Trans, 2013, 42: 14856

[8] Hagrman D, Zubieta C, Rose D J, Zubieta J, Haushalter R C. Angew Chem Int Ed, 1997, 36: 873

[9] Hagrman D, Zapf P J, Zubieta J. Chem Commun, 1998: 1283

[10] Wang X L, Li J, Tian A X, Zhao D, Liu G C, Lin H Y. Cryst Growth Des, 2011, 11: 3456

[11] Lan Q, Zhang J, Zhang Z M, Lu Y, Wang E B. Dalton Trans, 2013, 42: 16602

[12] Sun C Y, Liu S X, Liang D D, Shao K Z, Ren Y H, Su Z M. J Am Chem Soc, 2009, 131: 1883

[13] Sha J Q, Peng J, Zhang Y, Pang H J, Tian A X, Zhang P P, Liu H. Cryst Growth Des, 2009, 9: 1708

[14] Meng J X, Lu Y, Li Y G, Fu H, Wang E B. Cryst Growth Des, 2009, 9: 4116

[15] Uchida S, Hikichi S, Akatsuka T, Tanaka T, Kawamoto R, Lesbani A, Nakagawa Y, Uehara K, Mizuno N. Chem Mater, 2007, 19: 4694

[16] Dutta D, Jana A D, Debnath M, Bhaumik A, Marek J, Ali M. Dalton Trans, 2010, 39: 11551

[17] Wang Y, Wang L M, Li Z F, Hu Y Y, Li G H, Xiao L N, Wang T G, Zheng D F, Cui X B, Xu J Q. CrystEngComm, 2013, 15: 285
[18] Du J, Yu J H, Tang J Y, Wang J, Zhang W X, Thiel W R, Jia M J. Eur J Inorg Chem, 2011: 2361

[19] Sheldrick G M. SHELXL-97: A Program for Crystal Structure Determination. University of Göttingen, Germany, 1997

[20] Zang H Y, Du D Y, Li S L, Lan Y Q Yang G S, Yan L K, Shao K Z, Su Z M. J Solid State Chem, 2011, 184: 1141

[21] Lan Y Q, Li S L, Wang X L, Shao K Z, Du D Y, Zang H Y, Su Z M. Inorg Chem, 2008, 47: 8179

[22] Wang J, Zou Y C, Sun Y, Hemgesberg M, Schaffner D, Gao H C, Song X J, Zhang W X, Jia M J, Thiel W R. Chin J Catal (王静, 邹永存, 孙渝, Hemgesberg M, Schaffner D, 高洪成, 宋晓静, 张文祥,贾明君, Thiel W R. 催化学报), 2014, 35: 532

[23] Maiti S K, Abdul Malik K M, Gupta S, Chakraborty S, Ganguli A K, Mukherjee A K, Bhattacharyya R. Inorg Chem, 2006, 45: 9843

[24] Luz I, León A, Boronat M, Llabrés i Xamena F X, Corma A. Catal Sci Technol, 2013, 3: 371

[25] Brown K, Zolezzi S, Aguirre P, Venegas-Yazigi D, Paredes- García V, Baggio R, Novak M A, Spodine E. Dalton Trans, 2009: 1422

[26] Zhang S F, Miao C X, Xu D Q, Sun W, Xia C G. Chin J Catal (张淑芳, 苗 成霞,徐大乾, 孙伟, 夏春谷. 催化学报), 2014, 35: 1864

[27] Zhu X C, Shen R W, Zhang L X. Chin J Catal (朱学成, 沈如伟,张利雄. 催化学报), 2014, 35: 1716

\section{铜配合物修饰的钼氧簇超分子化合物催化烯烃环氧化}

高洪成 ${ }^{\mathrm{a}}$, 颜 岩 ${ }^{\mathrm{b}}$, 徐晓弘 ${ }^{\mathrm{c}}$, 于杰辉 ${ }^{\mathrm{b}}$, 牛会玲 ${ }^{\mathrm{b}}$, 高文秀 ${ }^{\mathrm{b}}$, 张文祥 ${ }^{\mathrm{b}}$, 贾明君 ${ }^{\mathrm{b}, *}$

a承德石油高等专科学校化学工程系, 河北承德 067000

b吉林大学化学学院, 吉林长春130021

c大庆油田总医院药剂科, 黑龙江大庆 163001

摘要: 近年来,含有过渡金属配合物和多金属氧酸盐的三维超分子化合物的合成与性能研究受到广泛关注. 利用过渡金属配合物 优良的可裁剪性和修饰性, 可以对多金属氧酸盐化合物的结构和性质进行有效调控, 进而构造出具有独特空间结构和性质的新 型功能材料. 这类材料往往具有多金属氧酸盐与过渡金属配合物两者结合的优点, 在医学、光学、磁性材料、气体吸附材料及催 化等领域显示出重要的学术研究价值和潜在的应用前景. 然而, 相比于在化合物合成及结构研究领域中的快速发展, 过渡金属配 合物修饰的多金属氧酸盐基化合物在催化领域中应用较少.

本文采用水热合成法, 以4, 4'-联吡定(bipy)或1,4'-双咪唑-1-甲基苯(bix)为氮杂环配体, 合成了两个铜配合物修饰的钿氧簇超分 子化合物催化剂, 分别记为 $[\mathrm{Cu}(\mathrm{bipy})]_{4}\left[\mathrm{Mo}_{15} \mathrm{O}_{47}\right] \cdot 2 \mathrm{H}_{2} \mathrm{O}(\mathbf{1})$ 和 $[\mathrm{Cu}(\mathrm{bix})]\left[(\mathrm{Cubix})\left(\delta-\mathrm{Mo}_{8} \mathrm{O}_{26}\right)_{0.5}\right]$ (2). 催化剂1 $\mathbf{1}$ 包含一个由铜的4, 4'-联吡 啶有机链修饰的钼氧簇链, 催化剂 2 是由 $1,4^{\prime}$-双咪唑-1-甲基苯有机配体、铜离子和八钿酸盐构筑的具有自穿插结构的超分子化合 
物. 通过以叔丁基过氧化氢为氧化剂的烯烃环氧化催化反应, 考察了两种催化剂的催化性能. 结果表明,催化剂1和2对环辛烯或1辛烯环氧化反应表现出较高的催化活性, 性能均明显优于未引入铜配合物的超分子化合物 $\left(\mathrm{H}_{2} \mathrm{bix}\right)\left[(\mathrm{Hbix})_{2}\left(\gamma-\mathrm{Mo}_{8} \mathrm{O}_{26}\right)\right] 2 \cdot \mathrm{H}_{2} \mathrm{O}(3)$; 在 相同反应条件下, 催化剂 $\mathbf{1}$ 表现出更高的催化活性; 溶剂种类显著影响催化剂的催化性能, 以乙腈为溶剂时, 苯乙烯环氧化反应主 产物为苯甲醛(仅有很少量的环氧化合物), 而以氯仿为溶剂时, 环氧化合物选择性显著提高; 中断实验和循环测试结果表明, 催化 剂1和2在1-辛烯环氧化反应中均表现出良好的稳定性和循环使用性.

FT-IR和XRD表征结果证实,经多次循环使用后催化剂结构基本保持不变,表明催化剂具有良好的结构稳定性. XPS表征结果 表明, 催化剂 1 中钼的正电性高于催化剂 2 , 这是由于配体类型不同及钿氧簇结构不同所致. 拥有较高正电性的钿物种通常会表现 出更高的催化烯烃环氧化反应能力, 这可能是催化剂 $\mathbf{1}$ 的催化活性优于催化剂 $\mathbf{2}$ 的主要原因. 此外, 通过结构分析可以看出, 催化剂 $\mathbf{1}$ 具有更开放的框架结构,这更有利于反应物扩散, 继而使催化剂表现出更高的催化活性. 需要指出的是,催化剂 $\mathbf{1}$ 和 $\mathbf{2}$ 中存在的铜配 合物也可能直接作为新的活性中心参与对氧化剂的活化, 继而对催化剂性能(活性和选择性)产生影响; 此外, 铜配合物与钿氧簇之 间较强的相互作用使所形成的超分子化合物具有良好的结构稳定性, 继而使这类超分子化合物催化剂表现出较为优异的稳定性 和循环使用性.

关键词: 超分子化合物; 钿氧簇; 铜配合物; 烯烃; 环氧化

收稿日期: 2015-05-01. 接受日期: 2015-05-29. 出版日期: 2015-11-20.

*通讯联系人. 电话: (0431)85155390; 传真: (0431)85168420; 电子信箱: jiamj@jlu.edu.cn

基金来源：国家自然科学基金(21173100和21320102001).

本文的英文电子版由Elsevier出版社在ScienceDirect上出版(http://www.sciencedirect.com/science/journal/18722067). 